\title{
Red Blood Cell Reagent Preparation
}

National Cancer Institute

\section{Source}

National Cancer Institute. Red Blood Cell Reagent Preparation. NCI Thesaurus. Code C113070.

Preparation of human red blood cells used to detect or identify blood-group antibodies for blood group determination. 